\title{
A Case of Fibrosing Mediastinitis Mimicking Malignant Mass Lesion with Tracheal Involvement, Diagnosed by Video-assisted Mediastinoscopy
}

\author{
Trakeal Tutulum ile Malign Kitle Lezyonunu Taklit Eden ve Video Yardımlı \\ Mediastinoskopi ile Tanı Alan Fibrozan Mediastinit Olgusu
}

Seher Susam', Berna Eren Komurcuoglu², Kenan Can Ceylan ${ }^{3}, \mathrm{Nur} \mathrm{Yücel}^{4}$

\begin{abstract}
A 27-year-old female patient was admitted with a complaint of cough and dyspnea, and was found to have a mediastinal mass lesion and tracheal stenosis on computed tomography. Other system examinations were usual. The transbronchial biopsy result was benign cytology. Magnetic resonance imaging (MRI) revealed no compression or invasion into vascular structures. The lesion was noted to be hypermetabolic in positron emission tomography (PRT) imaging. No benign or malignant differentiation could be based on the imaging findings. Due to a tracheal stricture, the patient underwent video-assisted mediastinoscopy for diagnosis and for the determination of a treatment approach. The procedure was successfully terminated upon the arrival of a frozen biopsy result with noncaseified fibrosing mediastinitis. The case is presented as a rare non-tumoral mediastinal disease that mimics malignancy and that was difficult to diagnose based on imaging findings.
\end{abstract}

Key words: Mediastinitis, fibrosis, computed tomography, magnetic resonant imaging, mediastinoscopy.

\section{Özet}

Öksürük ve dispne şikayeti ile başvuran 27 yaşındaki kadın hastanın, akciğer grafisi ve bilgisayarlı tomografi tetkikinde, trakeal stenoz oluşturan mediastinal kitle lezyonu saptandı. Diğer sistem muayeneleri normal idi. Transbronşial biyopsi sonucu ise benign olarak geldi. Manyetik rezonans görüntülemede vasküler yapılara bası ya da invazyon saptanmadı. Pozitron Emisyon Tomografisi ile görüntülemede lezyon hipermetabolik idi. Kitle lezyonunda görüntüleme bulguları ile benign ya da malign ayırımı yapılamadı. Trakeal striktür nedeniyle, tanı ve tedavi amacıyla olguya video yardımlı mediastinoskopi yapıldı, frozen biyopsi sonucunun non-kazeifiye fibrozan mediastinit gelmesi üzerine işlem başarı ile sonlandırılı. Maligniteyi taklit eden, görüntüleme bulguları ile tanısı zor nontümöral nadir mediastinal bir hastalık olması nedeniyle olgu sunulmuştur.

Anahtar Sözcükler: Mediastinit, fibrozis, bilgisayarlı tomografi, manyetik rezonans görüntüleme, mediastinoskopi.
'Departmant of Radiology, Health Sciences University Dr. Suat Seren Chest Disease and Thoracic Surgery Training and Research Hospital, İzmir, Turkey

${ }^{2}$ Departmant of Chest Disease, Health Sciences University Dr. Suat Seren Chest Disease and Thoracic Surgery Training and Research Hospital, İzmir, Turkey

${ }^{3}$ Departmant of Thoracic Surgery, Health Sciences University Dr. Suat Seren Chest Disease and Thoracic Surgery Training and Research Hospital, İzmir, Turkey

${ }^{4}$ Departmant of Pathology, Health Sciences University Dr. Suat Seren Chest Disease and Thoracic Surgery Training and Research Hospital, İzmir, Turkey
'Sağlık Bilimleri Üniversitesi, Dr Suat Seren Göğüs Hastalıkları ve Cerrahisi Eğitim ve Araşıırma Hastanesi, Radyoloji Bölümü, İmir

${ }^{2}$ Sağlık Bilimleri Üniversitesi, Dr Suat Seren Göğüs Hastalıkları ve Cerrahisi Eğitim ve Araştırma Hastanesi, Göğüs Has-

talıkları Bölümü, İzmir

${ }^{3}$ Sağlık Bilimleri Üniversitesi, Dr Suat Seren Göğüs Hastalıkları ve Cerrahisi Eğitim ve Araştırma Hastanesi, Göğüs Cerrahisi Bölümü, İzmir

${ }^{4}$ Sağlık Bilimleri Üniversitesi, Dr Suat Seren Göğüs Hastalıkları ve Cerrahisi Eğitim ve Araştırma Hastanesi, Patoloji Bölümü, Izmir

Submitted (Başvuru tarihi): 03.09.2020 Accepted (Kabul tarihi): 23.1 1.2020

Correspondence (iletişim): Seher Susam, Departmant of Radiology, Health Sciences University Dr. Suat Seren Chest Disease and Thoracic Surgery Training and Research Hospital, izmir, Turkey

e-mail: seher.susam@saglik.gov.tr 
Fibrosing mediastinitis (or mediastinal fibrosis/sclerosing mediastinitis) is a rare benign inflammatory disease characterized by the abnormal proliferation of mediastinal fibrous tissue with an unknown pathogenesis. It can mimic many malignant mass lesions, especially lymphoma and lung cancer, by causing compression and wall infiltration in vital organs (1). Computed tomography (CT) is the primary imaging method in the diagnosis of the disease (2), while Magnetic Resonance Imaging (MRI) provides additional information in the differential diagnosis of the lesion and the visualization of visceral structures (3). As in our case, this disease is as seen hypermetabolic in Positron emission tomography (PET) (4). Apart from tuberculous mediastinitis, it is a rare disease among nontumoral benign mediastinal mass lesions. Despite the many available radiological imaging methods, it is difficult to distinguish between the benign and malignant forms, and surgical intervention may sometimes be required for diagnosis and treatment. Video-assisted mediastinoscopy (VAM) holds particular value as a method that enables diagnosis without thoracotomy (4-6).

A rare and exemplary case whose malignancy could not be ruled out despite CT, MRI and PET CT imaging and a benign cytology, and who was considered for thoracotomy for the treatment of tracheal stenosis, but was diagnosed with VAM and improved with medical treatment, is presented here as an instructive case.

\section{CASE}

A 27-year-old woman presented to our hospital with a complaint of cough and dyspnea, and with no other findings other than stridor. Chest radiograph revealed a mild enlargement of the upper mediastinum and focal stenosis in the trachea, while a chest CT revealed an infiltrative solid mass lesion, starting at the lower thyroid gland, surrounding and narrowing the trachea, extending to the level of the carina and surrounding the brachiocephalic arteries (Figure la and b). No mediastinal/hilar lymphadenopathies were observed, lung parenchyma was normal, while mucosal involvement suggesting tumoral invasion in the trachea was detected in a fiberoptic bronchoscopic examination. The result of an endobronchial ultrasound-guided transbronchial fine-needle aspiration biopsy (FNAB) of the mass was nonspecific infection. Blood biochemistry and hemogram results were as expected except for mild anemia. Immunological tests and a microbiological examination revealed no diagnostic abnormalities.
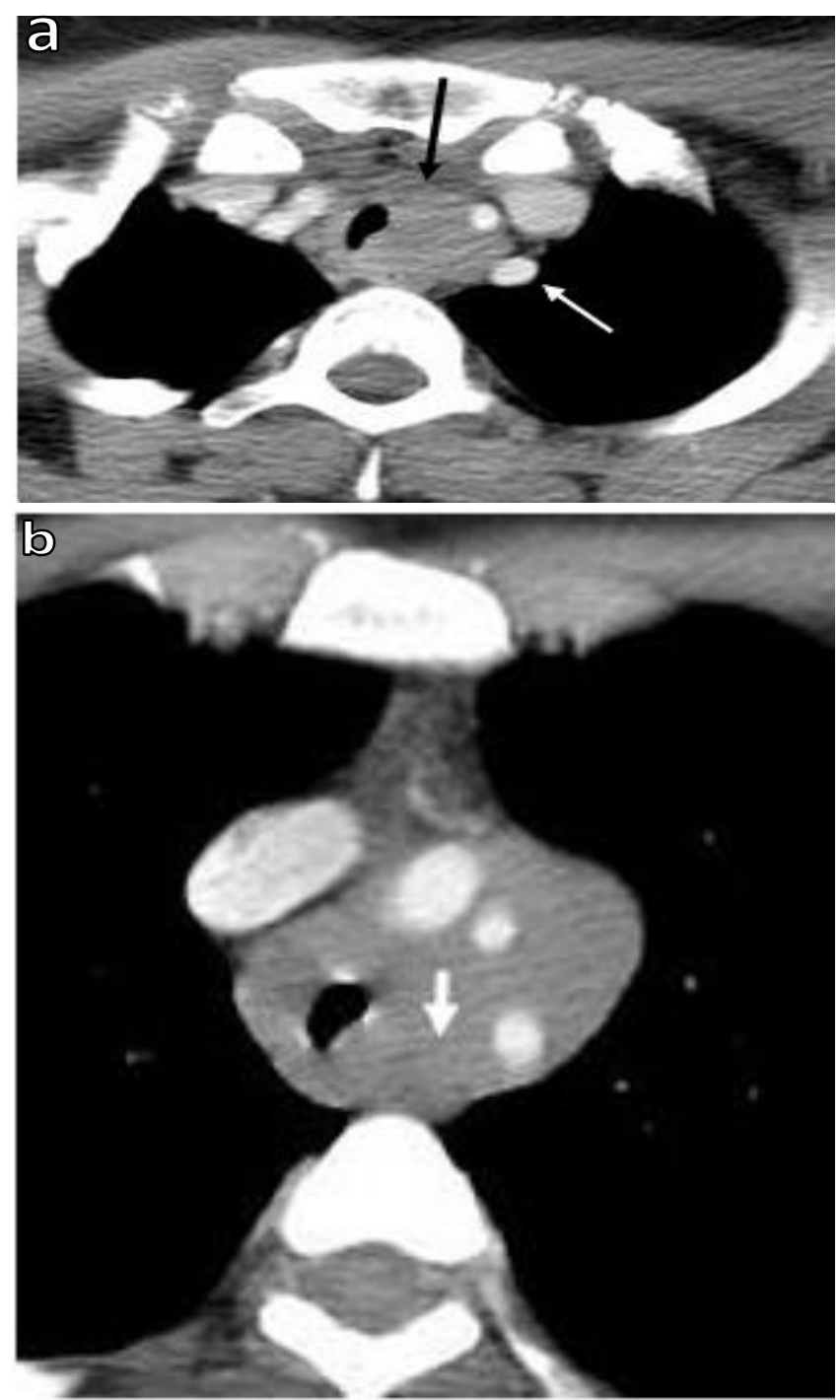

Figure 1a and b: A mass lesion with a solid density in the left paratracheal area (black arrow) that is displacing the left subclavian artery (white arrow) and the left main carotid artery, causing stenosis in the trachea (a) The mass lesion encasing the brachiocephalic artery, but not causing stenosis. Esophagus and mass interface cannot be distinguished (arrow) (b)

In the MRI, it is noteworthy that the regular calibrations of the vascular structures within the mass and the lack of significant contrast enhancement (Figure $2 a$ and b). The lesion was hypermetabolic (FDG SUV max: 11), and no other focus was detected in the PET CT (Figure 3). The patient underwent VAM due to suspicions of a malignant mass lesion (lung cancer, lymphoma, etc.) for diagnosis. Adequate diagnostic material was taken without complications, and the procedure was terminated after fibrosing mediastinitis was diagnosed from a frozen biopsy. A histopathologic examination with hematoxylin-eosin stain revealed that the lesion comprised mainly hyalinized fibrous tissue with an infiltration of polymorphonuclear cells, while no granulomatous or neoplastic lesions were present. 

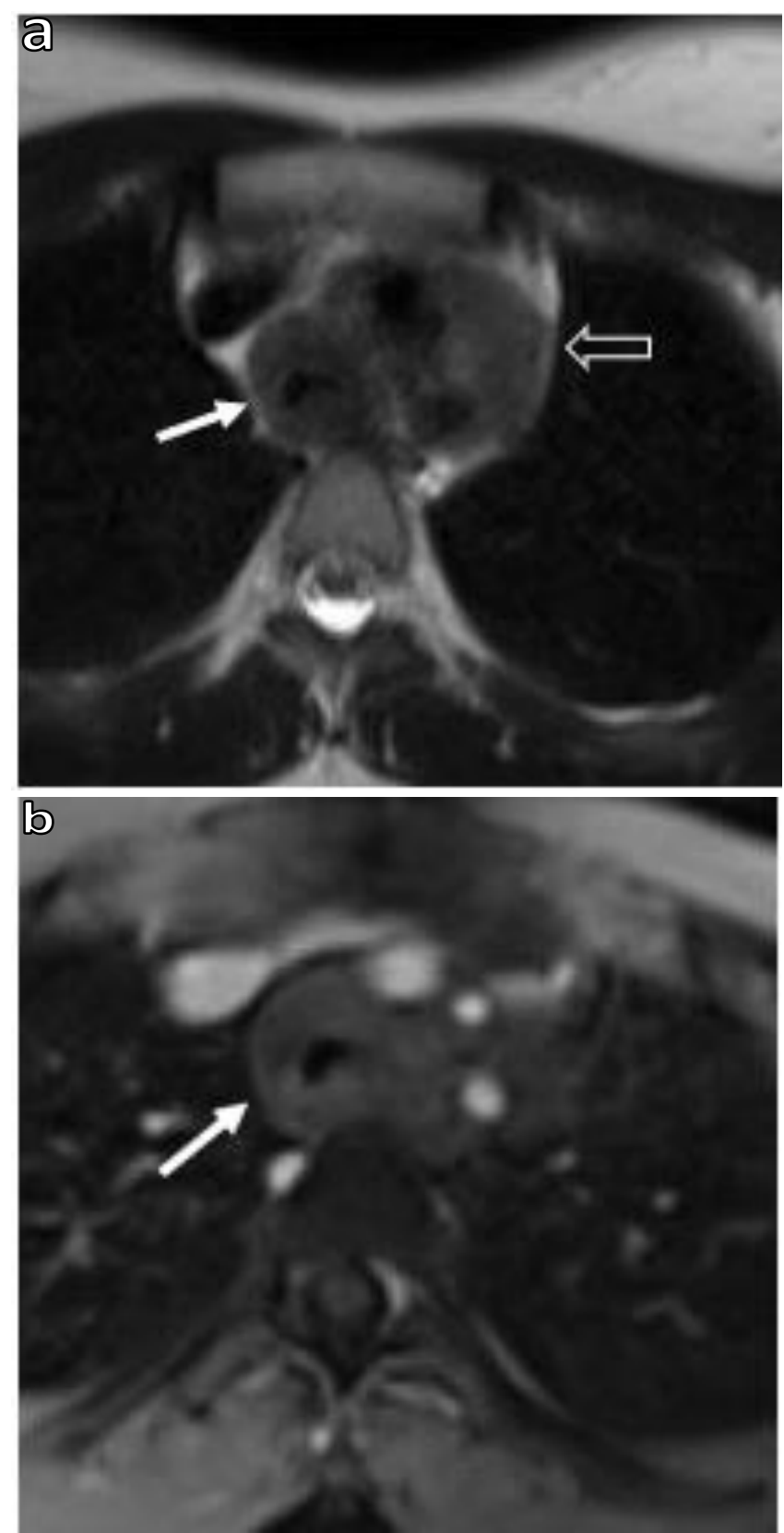

Figure $2 a$ and $b$ : The hypointense lesion on the T2W image, in which the encasement of the vascular structures (hollow arrow) and the tracheal stricture are clearly visible (white arrow) (a) Postcontrast TIW imaging revealing no significant enhancement in the lesion (arrow) (b)

The patent was started on $30 \mathrm{mg} /$ day corticosteroid treatment by accepting idiopathic inflammation (Figure 4), and the dose was reduced and eventually discontinued after near complete regression was noted at 1 month. The patient showed no sign of relapse at a 3-year followup (Figure 5).

\section{DISCUSSION}

Fibrosing mediastinitis is a rare disease with an unknown pathogenesis that is often seen in granulomatous infections, especially histoplasmosis, but is less often noninfec- tious or idiopathic, and can lead to mortality $(1,2)$. Flieder offers a clear description of the disease, referring to it as an "idiopathic fibroinflammatory disease of the mediastinum". Initially, the disease was considered to be an antigenic stimulation and immune reaction resulting from the direct spread from the lymph nodes to the mediastinum, or the opening of the lymph node to the reticuloendothelial system (1). It has also been shown to develop in other granulomatous infections, such as tuberculosis; aspergillosis; rheumatologic diseases such as Behcet's disease; and in sarcoidosis, radiotherapy and drug use (methysergide) (2). In the present case, tuberculosis cultures and serological tests were negative, and no etiological cause could be found and the case was accepted as idiopathic. The disease is common between the ages of 40 and 60, although the present case was 27 years old. The ratio of female and male patients is generally balanced (2).

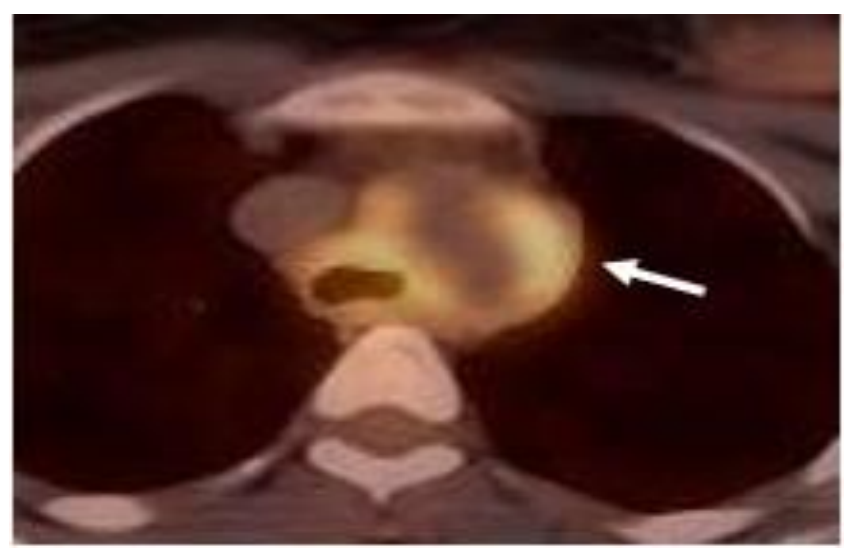

Figure 3: In PET CT, a high SUV 18 Flouro FDG uptake is observed (arrow)

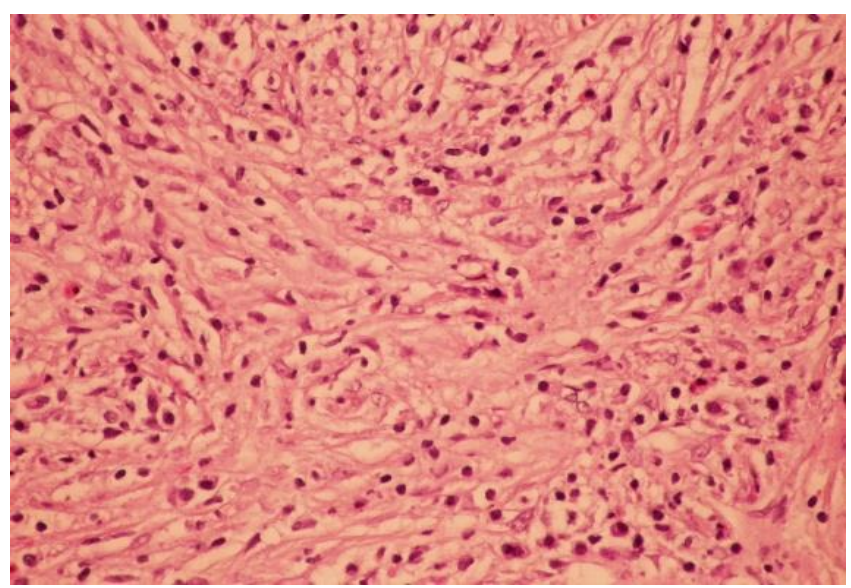

Figure 4: A histopathologic examination with hematoxylin-eosin stain revealed the lesion to comprise mainly hyalinized fibrous tissue, and with an infiltration of polymorphonuclear cells. No granulomatous or neoplastic lesions were present (original magnification $\times 400$ ) 
Pathologically, these lesions show heterogeneity. Flieder et al. (1) described a histopathologic spectrum of changes for which they established a three-step staging system: Stage I lesions are composed predominantly of edematous fibromyxoid tissue; Stage II lesions contain bands of glassy eosinophilic hyaline material surrounding and infiltrating the mediastinal structures. The findings of our patient are compatible with stage II, based on Flieder's classification.

CT is the primary radiologic imaging method (4), in which the involvement of the middle mediastinum, the right and left paratracheal, and subcarinal areas are often seen. A focal calcific mass was observed in $82 \%$ of the cases in the relatively wide series of 33 diseases reported on by Shernick, and granulomatous infection was detected in all these cases. In the remaining 18\%, a noncalcified infiltrating mass involving multiple compartments was detected, as in the present case, but was not associated with infection (2). Often, obstructions of the pulmonary artery, the vena cava superior and the main bronchus can be seen (5). CT findings are nonspecific. Especially in the non-calcified infiltrative form, metastasis, lymphoma, lung cancer the desmoid tumor may be included in a differential diagnosis (2). The advantage of MRI is its multiplanar imaging, and its ability to visualize vascular structures with special sequences in cases where a contrast material is contraindicated (3). PET CT is not routinely used for the diagnosis of the disease (6), although a small number of cases of sclerosing mediastinitis underwent PET CT after 1999.

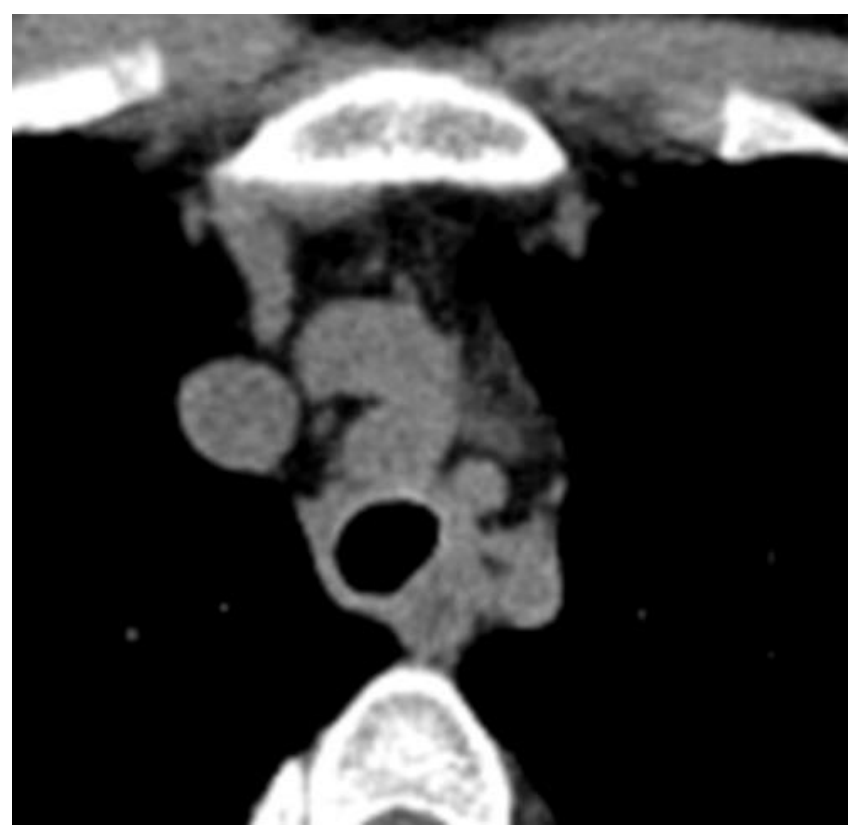

Figure 5: After treatment, the mass and tracheal stricture disappeared completely
Lesions may be hypo- or hypermetabolic (6), and so culture and histopathological diagnoses will be required. For surgical sampling, mediastinoscopy, thoracostomy or thoracotomy should be preferred over transbronchial biopsy $(4,5)$. VAM is a minimally invasive method for the histopathological examination of mediastinal diseases (5). With a standard VAM, biopsies can be taken from lymph nodes in the upper mediastinum, from the bilateral paratracheal and anterior subcarinal areas, as well as from mediastinal masses located in the paratracheal. Aside from allowing the safe sampling of lymph nodes, the use of mediastinoscopy for surgical treatment has witnessed a gradual increase, especially with the development of VAM In some publications, mediastinal cysts, especially bronchogenic cysts appear to be used successfully in excision (5). There is a possibility of complications or nondiagnostic material in mediastinitis due to the density of the fibrous tissue (4). In our patient, sufficient material was taken without complications. The CT images do not represent a specific to fibrous mediastinitis. Mediastinoscopic images of the mediastinum are more valuable, but at the time, no video recording of the patient could be made due to technical reasons.

The most important conclusion that can be drawn from this case is that mediastinal inflammatory mass lesions should be kept in mind in the differential diagnosis, not just malignancy and tuberculosis, especially in the young patient group. Invasions of visceral structures are seen not only in cases of malignancy. PET CT does not contribute to the differential diagnosis of active infections and malignancies due to its high SUV max values. In MR imaging it can be considered a clue that especially hyaline and collagen tissue generate different signals. In the present case, due to the aggressive radiological and clinical picture, the presence of a benign cytology from a fineneedle biopsy is considered a false-negative, and so tissue biopsy is preferred. VAM is highly valuable as a minimally invasive surgical diagnosis approach.

\section{CONCLUSION}

Imaging methods are the primary approach to the diagnosis of fibrosing mediastinitis, as well as in the planning of surgical treatment and in evaluations of the response to medical treatment, although the findings are nonspecific. PET CT makes no additional contribution to differential diagnosis, being a hypermetabolic disease involving malignant lesions or active infections. VAM, which is defined as a minimally invasive surgical technique in 
experienced hands, is considered the optimum approach to the diagnosis of extreme mediastinal diseases.

\section{CONFLICTS OF INTEREST}

None declared.

\section{AUTHOR CONTRIBUTIONS}

Concept - S.S., B.E.K., K.C.C., N.Y.; Planning and Design - S.S., B.E.K., K.C.C., N.Y.; Supervision - S.S., B.E.K., K.C.C., N.Y.; Funding - S.S., B.E.K., K.C.C.; Materials -; Data Collection and/or Processing - S.S., B.E.K., K.C.C., N.Y.; Analysis and/or Interpretation - S.S., B.E.K., K.C.C., N.Y.; Literature Review - S.S., B.E.K., K.C.C., N.Y.; Writing - S.S.; Critical Review - S.S., B.E.K., K.C.C., N.Y.

\section{YAZAR KATKILARI}

Fikir - S.S., B.E.K., K.C.C., N.Y.; Tasarım ve Dizayn - S.S., B.E.K., K.C.C., N.Y.; Denetleme - S.S., B.E.K., K.C.C., N.Y.; Kaynaklar - S.S., B.E.K., K.C.C.; Malzemeler -; Veri Toplama ve/veya İşleme - S.S., B.E.K., K.C.C., N.Y.; Analiz ve/veya Yorum - S.S., B.E.K., K.C.C., N.Y.; Literatür Taraması - S.S., B.E.K., K.C.C., N.Y.; Yazıyı Yazan S.S.; Eleştirel İnceleme - S.S., B.E.K., K.C.C., N.Y.

\section{REFERENCES}

1. Flieder DB, Suster S, Moran CA. Idiopathic fibroinflammatory (fibrosing/sclerosing) lesions of the mediastinum: a study of 30 cases with emphasis on morphologic heterogeneity. Mod Pathol 1999; 12:257-64.

2. McNeeley MF, Chung JH, Bhalla S, Godvin D. Imaging of granulomatous fibrosing mediastinitis. AJR Am J Roentgenol 2012; 199:319-27. [CrossRef]

3. Rholl KS, Levitt RG, Glazer HS. Magnetic resonance imaging of fibrosing mediastinitis. AJR Am J Roentgenol 1985; 145:255-9. [CrossRef]

4. Koksal D, Bayiz H, Mutluay N, Koyuncu A, Demirag F, Dagli $G$, et al. Fibrosing mediastinitis mimicking bronchogenic carcinoma. J Thorac Dis 2013;5:E5-E7.

5. Argueta F, Villafuerte D, Castaneda-Nerio J, Peters J, Restrepo C. Successful management of fibrosing mediastinitis with severe vascular compromise: Report of two cases and literature review. Respir Med Case Rep 2020; 29:100987. [CrossRef]

6. Imran MB, Kubota K, Yoshioka S, Yamada S, Sato T, Fukuda $H$, et al. Sclerosing mediastinitis: findings on fluorine-18 fluorodeoxyglucose positron emission tomography. Clin Nucl Med 1999; 24:305-8. [CrossRef] 